\title{
Density and distribution of the greater mole rat (Spalax microphthalmus) on the northern border of the area in a region of European Russia
}

\author{
Alexey V. Andreychev ${ }^{1 *}$, Alexandr S. Lapshin ${ }^{2}$ \\ ${ }^{1}$ Department of Zoology, National Research Mordovia State University, Bolshevistskaya Street 68, \\ 430005, Saransk, Russia \\ ${ }^{2}$ Biological Museum, National Research Mordovia State University, Ul'yanova Street 26 A, \\ 430019, Saransk, Russia \\ "corresponding author e-mail: teriomordovia@bk.ru
}

Received: 20 April 2020 / Accepted: 27 October 2020

\begin{abstract}
There are few subterranean mammals in Russia. The aim of the paper is to study the distribution and abundance of greater mole rat in the local population. The characteristic of the local population of the greater mole rat (Spalax microphthalmus) on the northern border of the range with reference to geographical coordinates is given. Our research has been conducted in Republic of Mordovia (European Russia). The field studies were carried out in 2007-2019. The population density in Mordovia is from 2 to 6 individuals/ha. The number of greater mole rat is estimated at 190 individuals. There are 27 to 200 mounds per one hectare of registered area. The distance of the greater mole rat habitat in Mordovia is from 40 to $372 \mathrm{~km}$ from other populations of neighboring regions. It is revealed that animals in the region are confined to pastures and dacha areas. The population density of subterranean rodent populations, such as mole rats, is in equilibrium with the capacity of the environment in which they live. The results on the population density and the number of greater mole rats on the northern border of the species range indicate the oppression of the local population.
\end{abstract}

Key words: subterranean mammals, mound, relative abundance, rodent, Republic of Mordovia.

\section{Introduction}

Herbivores, especially subterranean mammals, can influence per plants, soil structure and chemistry by moving soil (Williams \& Cameron, 1984; Andersen, 1987; Inouye et al., 1987; Benedix, 1993). There are few subterranean mammals in Russia. However, their role is significant in biotopes. They are almost unknown in many regions.

The habitat of the greater mole rat Spalax microphthalmus Guldenstaedt 1770 (Rodentia, Spalacidae) it covers areas with fertile soil and abundant vegetation. It lives in the steppe and forest-steppe of South-Eastern Europe between the Dnieper and the Volga, in the Western Cau- casus (Topachevskii, 1969; Flint et al., 1970; Puzachenko, 1993; Savchenko \& Ronkin, 2006). The Northern boundary runs from Kiev to the southern part of the Chernigov oblast, the Eastern part of the Kursk and Orel oblasts, in the southern outskirts of Tula, Ryazan, Tambov, Penza oblasts, Republic of Mordovia, Nizhny Novgorod oblast, the Chuvash Republic, Ulyanovsk oblast. The extreme Northern point of detection does not rise above the 56th parallel of the northern latitude (flood plain of the Bolshoi Civil, Chuvash Republic). The extreme North-Eastern point of detection is located in the Samara region (Samara oblast). The southern border of the area runs along the coast of the sea of Azov to the East in the South-Western part of the Krasnodar territory and rises in the Stavropol territo- 
ry to the North-East. The border then goes to the Volga North of Volgograd. South-Eastern borders have not been established yet (Puzachenko, 2011).

A great contribution was made to the study of the greater mole rat in Russian theriology by S. L. Ovchinnikova and A. Yu. Puzachenko. More attention to the ecology and biology of the species was given in Kursk, Voronezh, and Belgorod oblasts. For other regions, there is mainly fragmentary information, which, as a rule, is limited to a description of the distribution and status. The mole-rat has a rare species status in Tambov, Ryazan, Samara, and Ulyanovsk oblasts, as well as the republics of Mordovia and Chuvashia. In the context of the foregoing, the research in other regions, in particular, where relict local populations are preserved, is of significance. It is no coincidence that A.Yu. Puzachenko proposes to consider isolated populations as vulnerable or potentially vulnerable. The fact is that, at the end of the Pleistocene, mole-rats inhabited arid steppes, and with the onset of forests in the Holocene, the northern line of its range, as well as many other steppe species, shifted markedly southward and only a few populations remained in the former distribution boundaries. In the Volga region, mole-rat isolates were preserved in the refugia of steppe vegetation in Mordovia, Chuvashia, Nizhny Novgorod, and Samara oblasts.

Many researchers rightly point out that direct observations of the biology and ecology of mole-rat are difficult. This is due to the large length of individual burrows (up to hundreds of meters), seasonal changes in the configuration and direction of burrows on individual sites (Ovchinnikova, 1971; Rado \& Terkel, 1989; Puzachenko, 1993; Vlasov \& Puzachenko, 1993).

The aim of the paper is to study the distribution and abundance of greater mole rat in the local population at the border of the area. These tasks are relevant, since in the literature these aspects are not adequately addressed. In addition, in local animal populations under suboptimal conditions, differences in population density can be observed compared with populations of the main range of the species.

\section{Study area}

The studies were carried out in Ruzaevsky district of the Republic of Mordovia and Saransk urban district (geographical coordinates $54^{\circ} 05^{\prime}-54^{\circ} 09^{\prime} \mathrm{N}$ and $44^{\circ} 59^{\prime}-45^{\circ} 06^{\prime}$ E) (Fig. 1) in 2007-2019 and covered the entire habitat of mole rats in the region. The climate of the region is moderately continental with pronounced seasons throughout the year. The influx of direct solar radiation varies from 5.0 in December to $58.6 \mathrm{~kJ} / \mathrm{cm}^{2}$ in June. Total radiation throughout the year is $363.8 \mathrm{~kJ} / \mathrm{cm}^{2}$; the radiation balance is $92.1 \mathrm{~kJ} / \mathrm{cm}^{2}$. The average annual air temperature var- ies from 3.5 to $4.0{ }^{\circ} \mathrm{C}$. The average temperature of the coldest month (January) is in the range of $-11.5 \ldots-12.3$ ${ }^{\circ} \mathrm{C}$. Temperature drops down to $-47{ }^{\circ} \mathrm{C}$ occur. The average temperature of the warmest month, i.e. July, is in the range of $+18.9 \ldots+19.8{ }^{\circ} \mathrm{C}$. Extreme temperatures in the summer reach $37^{\circ} \mathrm{C}$. The average annual precipitation in the territory is $480 \mathrm{~mm}$. Over the course of observation lasting many years, periods of more and less humidification were noted, ranging between the minimum and maximum values of 120-180 mm. Distribution of precipitation across the territory is not very diverse. The average long-term value of evaporation is calculated to be in the range of 390-460 mm (Yamashkin, 1998).

\section{Material and Methods}

The degree of population of the territory on individual areas was determined by calculating the amount of land emissions on 1-hectare sites (Dukel'skaya, 1932; Gulyaevskaya, 1954; Pavlov et al., 1963; Puzachenko \& Vlasov, 1993). We carried out selective catches from burrows to determine the number of animals in burrow systems with subsequent release (Fig. 1). Catching was carried out in burrows until the noises of the passage of animals were recorded on dictaphones in the burrow. Studies were carried out according to a new methodology that we developed for studying of subterranean mammals (Andreychev, 2018; 2019; Andreychev et al., 2020). They also noted the absence of small animals after catching them in burrows where the ground was not covered with drafts.

Initially, the boundaries of individual habitats of mole rats were revealed, then the directions of the foraging passages were determined. The activity of animals may be surveyed with the use of voice recorders in different parts of colonies. The location of recorders was preliminarily determined on the basis of a map with consideration of the boundaries of animal colonies. A GPS-navigator was used for quick detection of recorders in the field.

When conducting scientific research, we used AIMP 1.75 (2007) and AUDACITY2.1.1 (2015) programs (Andreychev, 2018). During the research period, 200 sound recordings were obtained and processed, with a total length of about 16000 hours. We carried out 496 measurements of distances between mounds mole rats.

\section{Results}

It is revealed that the mole rat lives only in the central part of the region within the Saransk urban district and Ruzaevsky district. Natural and anthropogenic factors in Mordovia have long been limiting the further territorial settlement of this species. The settlement of mole rats to 


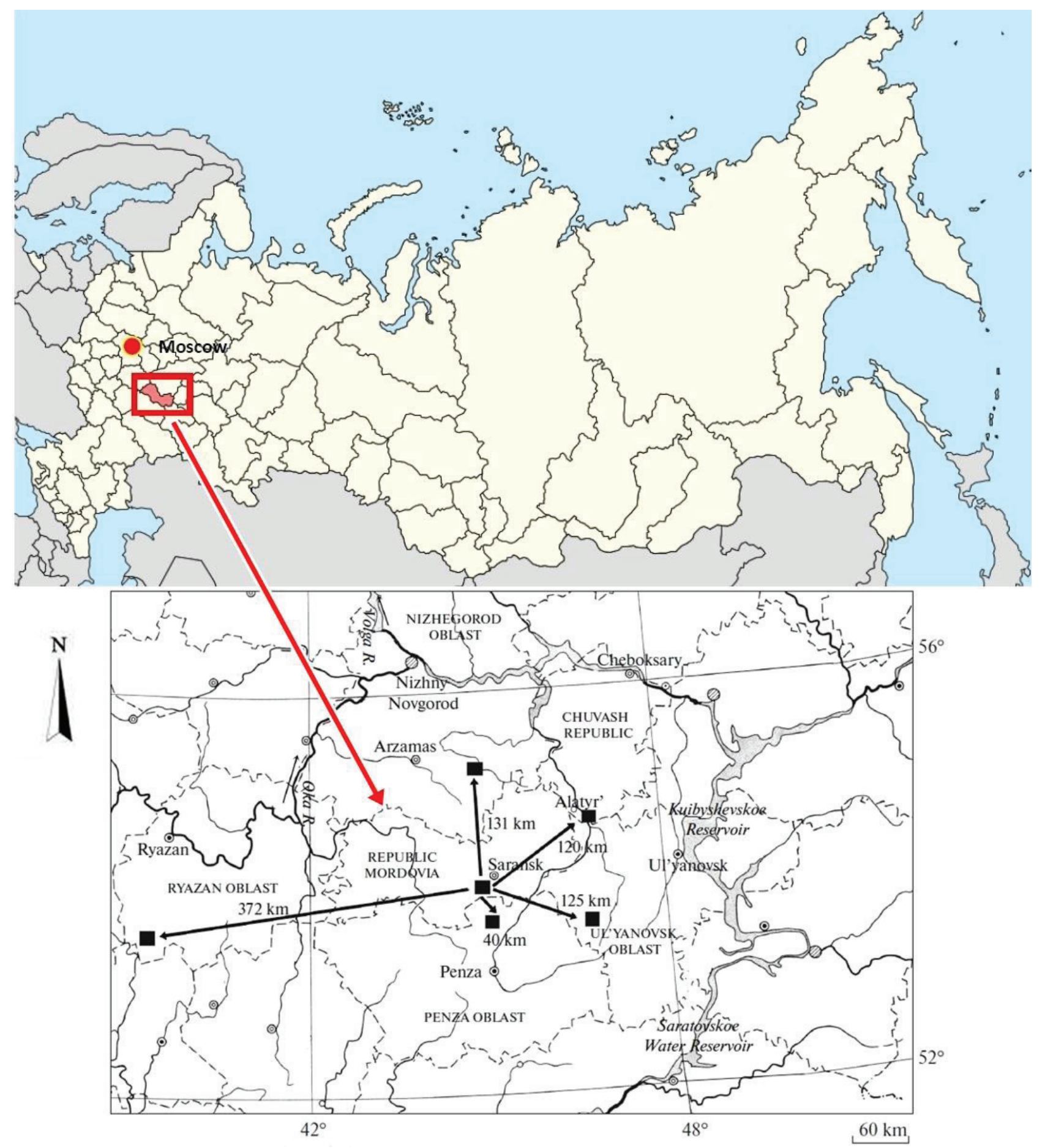

Figure 1. Geographical position of the Republic of Mordovia in Russia and distance of the local population of Spalax microphthalmus from other populations of neighboring regions.

Note: $\rightarrow-$ Remoteness of population with the distance indicated $(\mathrm{km})$

- Points of closest populations 
the west and south was limited by the Levzha River and its left tributaries, to the north, by the forest of Saransk, and to the east, by a road and the Insar River. A distinction was made using the OziExplorer program for 13 mole rat habitats (Table 1). The territory of detection of mole rat is currently more than $100 \mathrm{~km}^{2}$. The area was previously 26.8 $\mathrm{km}^{2}$ in 2010. However, the actual inhabited area is 568.3 ha. In 2010 , it was 297.7 ha (11.1\% of the total area). In the study area, the species does not populate fields sown with grain crops, tall grasses, and forest belts. It prefers meadows, pastures, summer cottages, and hayfields. It also settles near ponds and marshy areas.

However, the population of the mole rat is experiencing significant anthropogenic pressure. The mole rat was recorded on pastures, summer cottages, hayfields, and arable lands (Fig. 2). The animals prefer pastures and summer cottages, where from 27 to 200 mounds occur on 1 ha (Table 2).

Table 1. Number and area of the greater mole rat's habitat.

\begin{tabular}{|c|c|c|c|}
\hline Number habitat & Locality & Habitat area, ha & Number, individuals \\
\hline 1 & Levzhenskii & 32.4 & 4 \\
\hline 2 & Dobrovol'nyi & 16.8 & 8 \\
\hline 3 & Klyucharevo (South-East) & 183.8 & 6 \\
\hline 4 & Klyucharevo (North) & 3.4 & 60 \\
\hline 5 & Klyucharevo (West) & 12.5 & 11 \\
\hline 6 & Popovka & 28.2 & 12 \\
\hline 7 & Rybnyi & 110.6 & 18 \\
\hline 8 & Klyucharevskie Vyselki & 77.3 & 3 \\
\hline 10 & Levzha & 51.1 & 2 \\
\hline 11 & Yalga & 10.7 & 2 \\
\hline
\end{tabular}

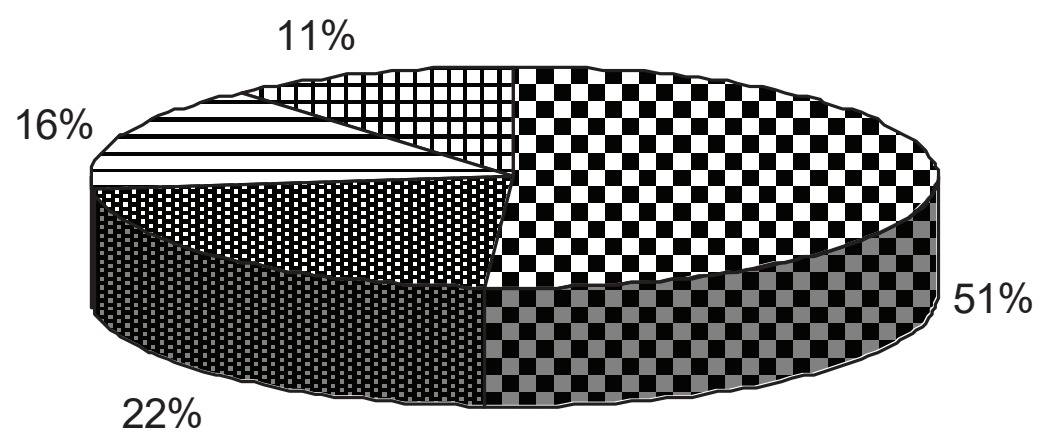

Figure 2. Occurrence of greater mole rat in various anthropogenic habitats in Mordovia.

Note: 1 - pastures; 2 - dacha areas, 3 - haymaking, 4 - arable land 
Table 2. Characteristics of trial registration areas (1 ha), habitats of S. microphthalmus.

\begin{tabular}{|c|c|c|c|c|c|}
\hline Site number & $\begin{array}{c}\text { Geographical } \\
\text { coordinates }\end{array}$ & Locality & $\begin{array}{c}\text { Length of } \\
\text { burrows, m }\end{array}$ & $\begin{array}{c}\text { Burrow } \\
\text { direction } \\
\text { (N,S,W,E) }\end{array}$ & $\begin{array}{c}\text { Density of mounds } \\
\text { per 1 ha }\end{array}$ \\
\hline I & $\begin{array}{c}54.1507 \mathrm{~N}, \\
44.9473 \mathrm{E}\end{array}$ & $\begin{array}{c}\text { Klyucharevskie } \\
\text { Vyselki }\end{array}$ & 160 & $\mathrm{~N}-\mathrm{S}$ & 200 \\
\hline II & $\begin{array}{c}54.1340 \mathrm{~N}, \\
45.0160 \mathrm{E}\end{array}$ & Klucharevo & 134 & $\mathrm{~N}-\mathrm{S}$ & 56 \\
\hline III & $\begin{array}{c}54.1200 \mathrm{~N}, \\
45.0289 \mathrm{E}\end{array}$ & Popovka & 125 & W-E & 105 \\
\hline IV & $\begin{array}{c}54.0998 \mathrm{~N}, \\
45.0964 \mathrm{E}\end{array}$ & Levzhenskii & 110 & W-E & 53 \\
\hline V & $\begin{array}{c}54.0928 \mathrm{~N}, \\
45.0192 \mathrm{E}\end{array}$ & Levzha & 71 & $\mathrm{~N}-\mathrm{S}$ & 25 \\
\hline VI & $\begin{array}{c}54.1329 \mathrm{~N}, \\
45.1316 \mathrm{E}\end{array}$ & Yalga & 281 & $\mathrm{~N}-\mathrm{S}$ & 50 \\
\hline VII & $\begin{array}{c}54.1170 \mathrm{~N}, \\
45.1770 \mathrm{E}\end{array}$ & Kulikovka & 95 & $\mathrm{~N}-\mathrm{S}$ & 30 \\
\hline VIII & $\begin{array}{c}54.0779 \mathrm{~N}, \\
45.1644 \mathrm{E}\end{array}$ & Monastyrskoe & 181 & $\mathrm{~N}-\mathrm{S}$ & 60 \\
\hline
\end{tabular}

The number of the greater mole rat in the total area of habitat in Mordovia was 190 individuals. Moreover, the distribution of land plots is uneven (Table 1). The population density varied from 2 individuals / ha (the villages of Monastyrskoe, the of Kulikovka, the of Novaya Nechayev$\mathrm{ka}$ ) to 6 individuals / ha (the villages of Klyucharevskie Vyselki, of the Klyucharevo, of the Popovka).

The primacy of animals changes to different anthropogenic habitats. Mole rats prefer to settle in the district of summer cottages near the village of Klucharevo. Mole rat inhabits the villages Rybnyi and Levzhenskii in the pastures around ponds. It should be noted that pastures in the Kursk region are considered a suboptimal biotope for the blind (Puzachenko \& Vlasov, 2012). This once again highlights the differences in the animal's biotopes in different regions.

The remoteness of the local mole rat population from other populations of neighboring regions differs. From the populations of the southern regions, namely, Penza and Ulyanovsk oblasts, which are part of the continuous range of the species, the habitat of mole rats from Mordovia is separated by a distance of about 40 and $125 \mathrm{~km}$, respectively. In Penza oblast, the closest biotopes where molerats live are Issinskii and Luninskii districts (Il'in et al., 2006). In Ulyanovsk oblast, the nearest habitat with respect to the population from Mordovia is located in the Bazarnosyzganskii district in the vicinity of the Yasachnyi Syzgan village (Abrakhina et al., 1993). As for identical isolated populations from the Chuvashia and Ryazan and Nizhny Novgorod oblasts, the distances to them from the extreme habitats of the mole rat in Mordovia are 120, 372, and 131 $\mathrm{km}$, respectively. In Chuvashia, only four local populations were noted, the nearest of which is in the Alatyr district (Dimitriev et al., 2010). In Nizhny Novgorod oblast, there are only two isolates in the Mezhp'yan'e (Sergachskii and Krasnooktyabr'skii districts) and on the left bank of the southern branch of the P'yana (the border of the Gaginskii and Shatkovskii districts) (Bakka, 2014). In Ryazan oblast, the habitat is known only on the slopes of the Panika River valley to the southeast of the Chernavskaya oak grove in Miloslavskii district (Didorchuk \& Kotyukov, 2012).

\section{Discussion}

We compared the current range boundaries of the mole rat with data on its distribution in Mordovia in the past (Astradamov et al., 1976; Andreychev et al., 2010; Andreychev, 2020). It should be noted that it significantly expanded the areas of their habitat (Fig. 3). In recent years the mole rat has managed to expand their habitat to the East to the village Kulikovka, West to the village Klyucharevskie Vyselki, South to the village Levzha. No settlement was registered in the North. In Mordovia, the distance between 
the edge detection points of mole rats from north to the south is currently $15 \mathrm{~km}$, and from the west to the east, 10 $\mathrm{km}$. In Mordovia, the distance between the edge detection points of mole rats from the north to the south was $10 \mathrm{~km}$ and from the west to the east, $8.8 \mathrm{~km}$ (Andreychev et al., 2010).
According to the results obtained in Mordovia and in the territories where the population density of S. microphthalmus is higher (Kursk oblast) (Puzachenko \& Vlasov, 1993), animals from our region have low (10-50 mounds per $1 \mathrm{ha}$ ) and medium (100-200 mounds per $1 \mathrm{ha}$ ) intensity of burrowing activity. The smallest occurrence of mounds

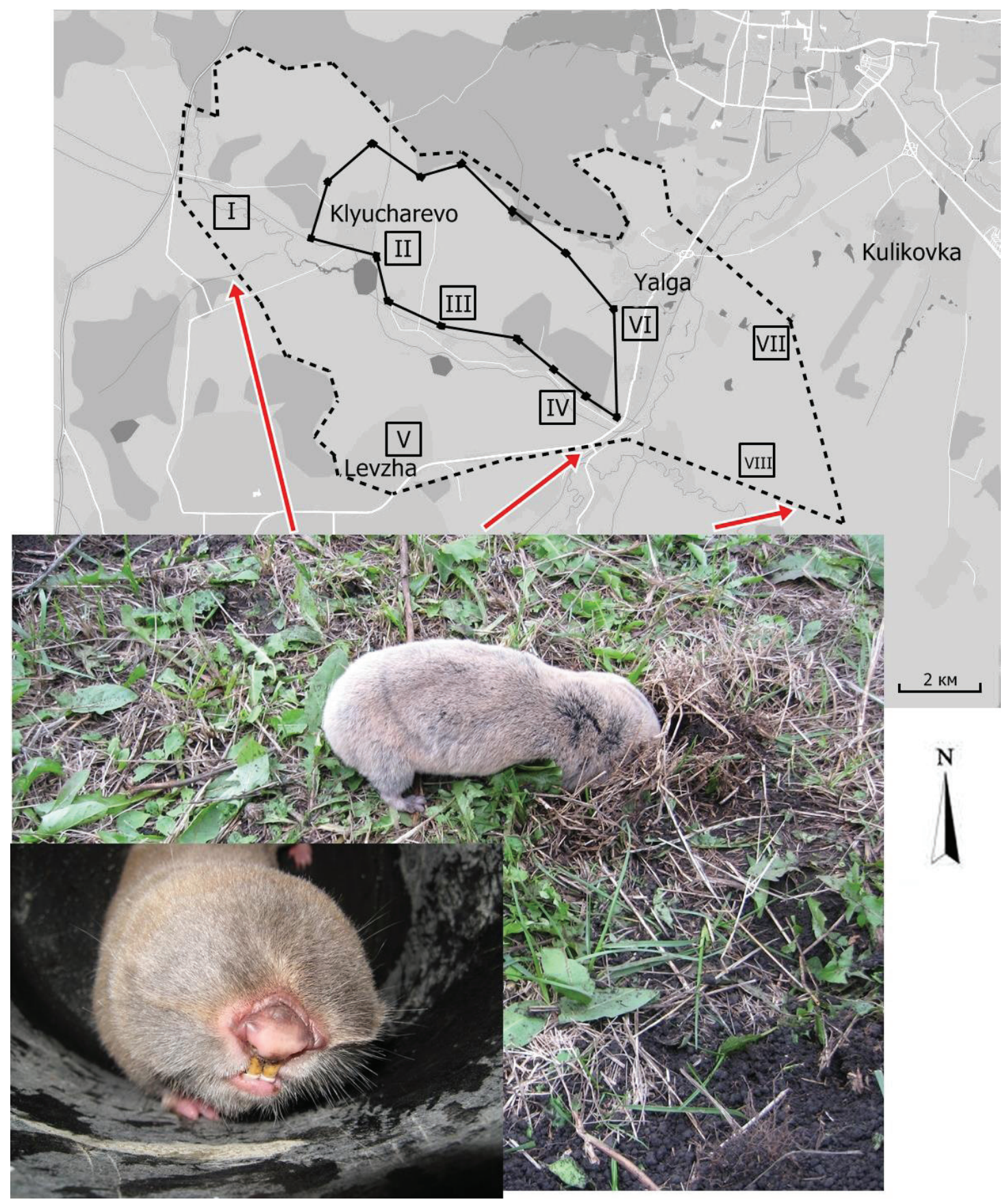

Figure 3. Geographic distribution of greater mole rat in the Republic of Mordovia. Note: A solid black line marks the former border of the greater mole rat habitat (Astradamov et al., 1976), and a dotted black line marks the current border of the greater mole rat habitat (our data, 2019). Black squares indicate the experimental areas for the registration of the greater mole rat (1 ha each). I-VII-site location numbers (see symbols in Table 1) 
mole rats was noted on agricultural arable lands and vegetable gardens; the first type of plots is rejected by the mounds itself, and from vegetable gardens it is actively expelled by humans. Under optimal habitat conditions, the mole rats can form up to 380 mounds per 1 ha, for example, in the steppe of the Lugansk oblast (Gulyaevskaya, 1954).

For comparison, the population density of $S$. microphthalmus was 2.6-4.9 individuals / ha in the Volga foreststeppe reserve in the Penza oblast in 1998-2004 (Il'yin et al., 2006). There, the blind man lives in a single undivided population. The population density for the Voronezh oblast varied from 3 to 20 individuals/ha (Ovchinnikova, 1971). The population density in the virgin steppe of the Lugansk oblast was from 1 to 11 individuals / ha (on average 3.7-3.8) (Gulyaevskaya, 1954).

The results of studying the burrowing activity of the mole rat are poorly displayed in many regions. It is advisable to provide the available data for some regions (Table 3). The data obtained for the territory of Mordovia are consistent with the results of other researchers $(\mathrm{Pu}-$ zachenko \& Vlasov, 1993; Didorchuk \& Kotyukov, 2012). However, the average depth of the upper edge of the stern passage is less in Mordovia $(13.2 \pm 1.49 \mathrm{~cm})$ than in the Kursk and Belgorod oblasts $(22.1 \pm 1.17 \mathrm{~cm})$. The obtained average value of distances between adjacent mounds for Mordovia. It is $3.5 \mathrm{~m}$. The average length of the burrow system is $70.7 \mathrm{~m}(\mathrm{n}=30)$ in Mordovia.

It was found that animals have different indicators of feeding passages in different types of anthropogenic changed habitats. They are slightly different from the same indicators in natural areas (meadows). It is noted that the most common land emissions occur in pastures and dacha plots. Sparseness is shown for haymaking and arable land. The lowest average depth of the upper edge of the stern passage is marked for suburban areas. The greatest weight of the thrown out earth from the passages is registered for haymaking. However, the regularity in the direction of the feeding course is shown from the North-East to the SouthWest for almost all types of anthropogenic habitats (more than $70 \%$ ) of the mole rat in Mordovia.

Cattle graze annually in the number of more than 150 individuals in many areas of the mole rat is habitat. In particular, this is typical for the village of Levzhenskii. We observed numerous failures of feeding passages in pastures. They were formed as a result of trampling the soil by cattle. S. microphthalmus in places of failures of feed passages conduct renewable activity. Gradually, new earth emissions appear. Researchers have found that the appearance of new mounds is a reliable marker of employment of the optimal territory (Zhukov et al., 2011).

Many researchers note that the mole rat can often be found in forest belts (Topachevskii, 1969; Ovchinnikova, 1971). The mole rat avoids these habitats in Mordovia. The nearest mounds were found at a distance of 40 meters. It was on a pasture near the village of Levzhenskii and 60 meters away on a pasture near the village of Klyucharevo.

It is very interesting to compare the features of burrowing activity in different types of mole rat. For example, the Riesen-Blindmaus Spalax giganteus in the Terek-Kumskoe interfluve in the Caucasus. The number of mounds per 1 ha varied from 32 to 456, (on average 181) (Pavlov et al., 1963). The population density of the $S$. giganteus reached 0.5-2 individuals / 1 ha, in the area of the Talovka River (Dagestan) in August 1991 (Puzachenko, 1999). At the same time, the average distance between the mounds was about $5 \mathrm{~m}$.

According to A. Yu. Puzachenko, the same burrow system is inhabited by a sexually Mature female and male greater mole rat. Besides them, fingerlings can be caught. In this regard, the researcher introduced a classification of burrow systems by the size and composition of their inhabitants. He identified three groups of settlements of the greater mole rat. The first group consists of complex burrow systems extending for hundreds of meters, where adult males, females and youngsters live together. The sec-

Table 3. Some characteristics of burrowing activity of S. microphthalmus in different regions

\begin{tabular}{|c|c|c|c|c|}
\hline \multirow{2}{*}{ Region } & \multicolumn{3}{|c|}{ Characteristic } & \multirow{2}{*}{ Source } \\
\cline { 2 - 5 } & $\begin{array}{c}\text { Average distance } \\
\text { between neighboring } \\
\text { mounds, m }\end{array}$ & $\begin{array}{c}\text { Average depth } \\
\text { of burrow from the } \\
\text { soil surface, cm }\end{array}$ & $\begin{array}{c}\text { Average mounds soil } \\
\text { weight, kg }\end{array}$ & $\begin{array}{c}10.6 \pm 1.63 \\
(\mathrm{n}=25)\end{array}$ \\
\hline $\begin{array}{c}\text { Kursk and Belgorod } \\
\text { oblasts }\end{array}$ & $\begin{array}{c}1.9 \pm 0.07 \\
(\mathrm{n}=491)\end{array}$ & $\begin{array}{c}22.1 \pm 1.17 \\
(\mathrm{n}=285)\end{array}$ & - & $\begin{array}{c}\text { Puzachenko, Vlasov, } \\
1993\end{array}$ \\
\hline Ryazan oblast & $\begin{array}{c}1.4 \pm 0.2 \\
(\mathrm{n}=14)\end{array}$ & - & $\begin{array}{c}10.3 \pm 0.44 \\
(\mathrm{n}=280)\end{array}$ & Own data, 2019 \\
\hline Mordovia & $\begin{array}{c}3.5 \pm 0.12 \\
(\mathrm{n}=496)\end{array}$ & $\begin{array}{c}13.2 \pm 1.49 \\
(\mathrm{n}=280)\end{array}$ \\
\hline
\end{tabular}


ond group includes systems that are less extensive (tens or hundreds of meters) and contain only one individual. The third group is formed by the norms of fingerlings that have separated along the periphery of the family's habitat. The length of such burrows is insignificant (tens of meters) (Puzachenko, 1993). According to this classification, the first two groups of settlements are found in Mordovia. They are inhabited by several individuals (settlements near the village of Levzhenskii, the village of Klyucharevo, Popovka, Klyucharevskie Vyselki) and only one individual (Dobrovol'nyi, Novaya Nechayevka, Monastyrskoe, Kulikovka).

The population density of the Palestine mole rat Spalax ehrenbergi in Israel ranged from 91 to 177 individuals per $1 \mathrm{~km}^{2}$ (1 to 1.8 individuals / ha) (Nevo et al., 1982). According to other data, the population density of Spalax golani varied in Israel from 2 to 10 individuals / ha (Lovy et al., 2015). However, the population density of different researchers is within the range of variation for this species from 0.1 to 20 individuals/ha (Savic \& Nevo, 1990). The population density of other subterranean mammals is 4.6-5.2 individuals / ha (Sumbera et al., 2003, 2008). These figures in terms of population density do not differ significantly from $S$. microphthalmus.

The area and length of the burrows of the greater mole rat are similar to other subterranean mammals. The estimated density of mound clusters was $26 \pm 21$ clusters per $\mathrm{km}^{2}$. The average and estimated cluster sizes were four mounds per cluster. Estimated density of $94 \pm 79$ mounds per $\mathrm{km}^{2}$ (Quinn et al., 2010).

The density Pocket gophers (Geomys breviceps) is 1.35 gophers per acre in Texas (Davis et al., 1938). In Texas, densities Geomys bursarius ranged from 1.3, 16.0, and 18.7 individuals / ha in pastureland, riparian sandbar, and hayfield, respectively (Broussard, 1996). Average density estimates per hectare were 20.4 (range 4.0-60.4) in Arkansas (Connior et al., 2010), 7.4-9.9 in Indiana (Mohr \& Mohr, 1936), 12.9 in Wisconsin (Zinnel, 1992), and 5.422.0 in Minnesota (Adams, 1966). Smallwood and Morrison (1999) determined that generally much of the variation can be explained by the size of the study area (Connior, 2011). Average home range sizes for adult female and adult male of the Ozark pocket gopher ( $G$. bursarius ozarkensis) in Arkansas over 2 y of $287.1 \mathrm{~m}^{2}$ and $291.8 \mathrm{~m}^{2}$ (Connior \& Risch, 2010).

The habitat of the zokor is larger than that of the mole rat. The home range of a male zokor exceeds $1500 \mathrm{~m}^{2}$ and is larger than a female range of less than $500 \mathrm{~m}^{2}$ (Zhou $\&$ Dou, 1990). The distribution and population density of plateau zokors are limited by elevation, vegetation, precipitation, and anthropogenic disturbance (Zhang et al., 1999). It was estimated that they occupied a range of approximately $3.8 \times 106$ ha at an average density of 15 individuals / ha, but ranging from five to more than 70 per hectare in
Qinghai province in the 1980s (Wang \& Fan, 1987; Zhang et al., 1999; Zhang et al., 2003; Zhang, 2007). This population density of the zokor is several times higher than that of the greater mole rat.

\section{Conclusions}

Thus, it can be concluded that the population density of subterranean rodent populations, such as mole rats, is in equilibrium with the capacity of the environment in which they live. The population density of the greater mole rat in Mordovia varied from 2 to 6 individuals / ha. The number in the total area of habitat was 190 individuals. The results on the population density and the number of greater mole rats on the northern border of the species range indicate the oppression of the local population. In most subterranean mammals species a population's growth rate is a decreasing function of density. This explains the relative stability of animal populations, which never continue to increase at rates their fertility would allow, and rarely decrease to extinction (Tanner, 1966).

\section{Acknowledgement}

We are grateful to G. F. Salmov and R. M. Kulahmetov for support in carrying out of field studies. We are grateful to two anonymous reviewers for their constructive comments and feedback on an earlier version of this paper.

\section{References}

Abrakhina I.B., Osipova V.B. \& Tsarev G.N., 1993, Pozvonochnye zhivotnye Ul'yanovskoi oblasti (Vertebrates of the Ulyanovsk Oblast), Ul'yanovsk: 50-63. [in Russian].

Adams G.D., 1966, Populations and spatial distribution of pocket gophers (Geomys b. bursarius). Ph.D. dissertation, University of Minnesota, Minneapolis.

Andersen D.C., 1987, Geomys bursarius burrowing patterns: influence of season and food patch structure. Ecology 68: 1306-1318.

Andreychev A.V., 2018, A new methodology for studying the activity of underground mammals. Biology Bulletin 45: 937-943. http://dx.doi.org/10.1134/ S1062359018080022

Andreychev A.V., 2019, Daily and seasonal feeding activity of the greater mole-rat (Spalax microphtalmus, Rodentia, Spalacidae). Biology Bulletin 46: 1172-1181. http://dx.doi.org/10.1134/S1062359019090012

Andreychev A., 2020, Proportion faunal assemblage of rodents in geoecological districts of Mordovia, Rus- 
sia. Biodiversitas 21(9): 3961-3968. http://dx.doi. org/10.13057/biodiv/d210906

Andreychev A.V., Lapshin A. S. \& Kuznetsov V. A., 2010, On the spread of the greater mole rat in the Republic of Mordovia. XXXVIII Ogaryov Readings. Publisher of the Mordovia State University: Saransk: 13-14. [in Russian].

Andreychev A., Kuznetsov V., Lapshin A. \& Alpeev M., 2020, Activity of the Russian desman Desmana moschata (Talpidae, Insectivora) in its burrow. Therya 11(2): 161-167. http://dx.doi.org/10.12933/therya-20-801

Astradamov V.I., Vechkanov V.S., Machinskii A.P. \& Zadal'skii S.V., 1976, The blind mole rat in Mordovia and its helminthofauna, in Ekologicheskie issledovaniya nazemnykh I vodnykh zhivotnykh v Mordovii (Ecological Studies of Terrestrial and Aquatic Animals in Mordovia), Publisher of the Mordovia State University: Saransk, pp. 61-69. [in Russian].

Bakka S.V., 2014, Blind mole rat, in Krasnaya kniga Nizhegorodskoi oblasti (The Red Data Book of the Nizhny Novgorod Oblast), vol. 1: Zhivotnye (Animals), 2nd ed. Nizhny Novgorod, pp. 65-67. [in Russian].

Benedix J.H., 1993, Area-restricted search by the plains pocket gopher (Geomys bursarius) in tallgrass prairie habitat. Behavioral Ecology 4(4): 318-324. http:// dx.doi.org/10.1093/beheco/4.4.318

Broussard D.R., 1996, The relationships between population demographics of Geomys bursarius and the variability of its food base. M.S. thesis, Baylor University, Waco, Texas.

Connior M.B., 2011, Geomys bursarius (Rodentia: Geomyidae). Mammalian Species 43: 104-117. http:// dx.doi.org/10.1644/879.1

Connior M.B. \& Risch T.S., 2010, Home Range and Survival of the Ozark Pocket Gopher (Geomys bursarius ozarkensis) in Arkansas. The American Midland Naturalist 164(1): 80-90. http://dx.doi.org/10.1674/00030031-164.1.80

Connior M.B., Kershen A.A., Medlin R.E., Elrod D.E., Sasse D.B. \& Risch T.S., 2010, Distribution and habitat affinities of an endemic pocket gopher. American Midland Naturalist 164: 217-229.

Davis W.B., Ramsey R.R. \& Arendale J.M., 1938, Distribution of Pocket Gophers (Geomys Breviceps) in Relation to Soils. Journal of Mammalogy 19(4): 412-418. http://dx.doi.org/10.2307/1374224

Didorchuk M.V. \& Kotyukov Yu.V., 2012, Data on the current distribution of the blind mole rat in the Ryazan oblast. Actual Problems of Modern Mammalogy, Novosibirsk, $12 \mathrm{pp}$. [in Russian].

Dimitriev A.V., Konovalenko A.V., Rakhmatullin M.M. \& Sinichkin E.A., 2010, Blind mole rat. The Red Data Book of the Chuvash Republic, Cheboksary, 278 pp. [in Russian].
Dukel'skaya N.M., 1932, Biology of the greater mole rat and testing different methods to combat. Tr. Zashch. Rast. 4(2): 23-46. [in Russian].

Flint V.E., Chugunov Yu.D. \& Smirin V.M., 1970, Mammals of the USSR. Mysl', Moscow. [in Russian].

Gulyaevskaya N.S., 1954, Digging activity (Spalax micropthalmus Guld) and its landscape and agricultural significance, Extended Abstract. Cand. Sci. (Biol.) Dissertation, Moscow. [in Russian].

Il'in V.Yu., Bystrakova N.V., Dobrolyubov A.N., Ermakov O.A., Zolina N.F., et al., 2006, Synapsis of mammalian fauna of the Penza oblast. Izv. Penz. Gos. Pedagog. Univ. im. V.G. Belinskogo 1(5): 73-89. [in Russian].

Inouye R.S., Huntly N.J., Tilman D. \& Tester J.R., 1987, Pocket gophers (Geomys bursarius), vegetation, and soil nitrogen along a successional sere in east central Minnesota. Oecologia 72: 178-184. http://dx.doi. org/10.1007/BF00379264

Lovy M., Skliba J., Hrouzkova E., Dvorakova V., Nevo E. \& Sumbera R., 2015, Habitat and burrow system characteristics of the blind mole rat Spalax galili in an area of supposed sympatric speciation. PLoS ONE 10(7): e0133157. http://dx.doi.org/10.1371/journal. pone. 0133157

Mohr C.O. \& Mohr W.P., 1936, Abundance and digging rate of pocket gophers, Geomys bursarius. Ecology 17: 325-327.

Nevo E., Heth G. \& Beiles A., 1982, Population structure and evolution in subterranean mole rats. Evolution 36(6): 1283-1289.

Ovchinnikova S.L., 1971, Distribution of the greater mole rat (Spalax microphthalmus Guld.) in the southeastern part of the Black Earth Center. Tr. Voronezh. Univ. 93: 80-83. [in Russian].

Pavlov A.N., Vasilenko V.S., Kolesnikov I.M., Myalkovskaya S.A. \& Potapova E.A., 1963, On the modern distribution of the Riesen-Blindmaus Spalax giganteus in the north-eastern Ciscaucasia. Zoologicheskii Zhurnal 42(5): 777-780. [in Russian].

Puzachenko A.Yu., 1993, Space pattern of the microgroupings in subterranean mole rat Spalax microphthalmus (Rodentia, Spalacidae) populations. Mammalia 57(4): 619-648.

Puzachenko A.Yu., 1999, Methodology for assessing the environmental status of representatives of the family of mole rats (Sapacidae, Rodentia) of mole rats. Rare species of mammals in Russia and neighboring countries. Moscow: 317-329. [in Russian].

Puzachenko A.Yu., 2011, Greater mole-rat, Biodiversity Conservation Center, http://www.biodiversity.ru/programs/rodent/species/spalax_microphthalmus.html [Accessed January 27, 2016].

Puzachenko A.Yu. \& Vlasov A.A., 1993, Diggin activity of the mole rat Spalax microphthalmus (Rodentia, 
Spalacidae). Zoologicheskii Zhurnal 72(11): 91-103. [in Russian].

Puzachenko A.Yu. \& Vlasov A.A., 2012, The dynamics of the population density of the greater mole rat (Spalax microphthalmus, Rodentia) in the "Streletskaya Steppe". Regimes of Specially Protected Steppe Areas: Proc. Int. Sci.-Pract. Conf. Dedicated to the 130th Anniversary of Birthday of Professor V.V. Alekhin, Kursk: 161-168. [in Russian].

Quinn V.S., Tsai C.C. \& Zollner P.A., 2010, Distribution of the Plains Pocket Gopher (Geomys bursarius) in the grassland physiographic regions of Indiana. Proceedings of the Indiana Academy of Science 119(1): 87-94.

Rado R. \& Terkel J., 1989, A radio-tracking system for subterranean rodents. Journal Wildlife Manag. 53(4): 946-949.

Savic I.R. \& Nevo E., 1990, The Spalacidae: evolutionary history, speciation and population biology, [in:] E. Nevo, O.A. Reig (eds), Evolution of subterranean mammals at the organismal and molecular levels. Alan R. Liss, Inc., V, New York, 335: 129-153.

Savchenko G.A. \& Ronkin V.I., 2006, The role of the original and introduced heterogeneity in the formation of the complexity of steppe ecosystems of northeastern Ukraine, Vestn. Khar'kov. Nats. Univ. im. V.N. Karazina 729: 185-192.

Smallwood K.S. \& Morrison M.L., 1999, Spatial scaling of pocket gopher (Geomyidae) density. Southwestern Naturalist 44: 73-82.

Sumbera R., Burda H., Chitaukali W.N. \& Kubova J., 2003, Silvery mole-rats (Heliophobius argenteocinereus, Bathyergidae) change their burrow architecture seasonally. Naturwissenschaften 90: 370-373.

Sumbera R., Skliba J., Elichova M., Chitaukali W.N. \& Burda H., 2008, Natural history and burrow system architecture of the silvery mole-rat from Brachystegia woodland. Journal of Zoology 274: 77-84.

Tanner J.T., 1966, Effects of Population Density on Growth Rates of Animal Populations. Ecology 47(5): 733-745. http://dx.doi.org/10.2307/1934260

Topachevskii V.A., 1969, Spalacidae, Fauna of the USSR. Mammals, Leningrad: Nauka: 3(3). [in Russian].
Vlasov A.A. \& Puzachenko A.Yu., 1993, Distribution of the greater mole rat (Spalax microphthalmus Guldenstaedt 1770, Rodentia, Spalacidae) burrow systems in the protection meadow steppe. Russian Journal of Ecology 4: 88-90. [in Russian].

Wang Q. \& Fan N., 1987, Studies on the digging activities and exploration about the method of number estimation of plateau zokor. Acta Theriologica Sinica 7: 283- 290.

Williams L.R. \& Cameron G.N., 1984, Demography of dispersal in attwater's pocket gopher (Geomys attwateri). Journal of Mammalogy 65(1): 67-75. http:// dx.doi.org/10.2307/1381201

Yamashkin A.A., 1998, Physico-geographical conditions and landscapes of Mordovia. (Yamashkin, A.A., ed.). Publisher of Mordovia State University. Saransk, Russia, $156 \mathrm{pp}$.

Zhang Y., 2007, The Biology and Ecology of Plateau Zokors (Eospalax fontanierii), [in:] S. Begall, H. Burda, C.E. Schleich (eds), Subterranean Rodents. Springer, Berlin: Heidelberg. http://dx.doi.org/10.1007/978-3540-69276-8_17

Zhang Y., Fan N. \& Wang Q., 1999, The effects of some environmental factors on population abundance of plateau zokor. Acta Biologica Plateau Sinica 14: 101-109.

Zhang Y., Zhang Z. \& Liu J., 2003, Burrowing rodents as ecosystem engineers: the ecology and management of plateau zokors Myospalax fontanierii in alpine meadow ecosystems on the Tibetan Plateau. Mammal Review 33(3-4): 284-294. http://dx.doi.org/10.1046/j.13652907.2003.00020.x

Zhou W. \& Dou F., 1990, Studies on activity and home range of plateau zokor. Acta Theriologica Sinica 10: 31-39.

Zhukov A.V., Kunakh O.N. \& Konovalova T.M., 2011, The landscape aspect of the ecological niche of mole rats (Spalax micropthalmus Guldenstaedt 1770). Biological textbook of the Melitopol Sovereign Pedagogical University im. Bogdan Khmelnitsky 3: 13-27.

Zinnel K.C., 1992, Behavior of free-ranging pocket gophers. Ph.D. dissertation, University of Minnesota, Minneapolis. 